\title{
Repair of Wall Damage in Escherichia coli Recovered from an Aerosol
}

\author{
By P. HAMBLETON \\ Microbiological Research Establishment, Porton, Salisbury, Wiltshire
}

(Accepted for publication II August 1971)

\begin{abstract}
SUMMAR Y
Escherichia coli в organisms recovered from aerosols had a changed envelope as manifested by the bacteria becoming sensitive to lysozyme. Certain di- and trivalent cations added to suspensions of bacteria recovered from aerosols mitigated this sensitivity. Repair required a carbon-energy source, but not synthesis of protein, ribonucleic acid or mucopeptide. Components of the envelope were released from the aerosolized organisms. These results support the hypothesis that aerosolization caused changes in the outer wall structure of bacteria that resemble changes induced by ethylenediaminetetraacetic acid.
\end{abstract}

\section{INTRODUCTION}

Aerosolization profoundly affects the permeability of some Gram-negative bacteria. Micro-organisms recovered from aerosols lack control of ion transport (Anderson, Dark \& Peto, 1968) and certain cytoplasmic constituents leak out (Benbough, I967; Cox, I969; Webb, 1969; J. E. Benbough, P. Hambleton \& R. E. Strange, unpublished results). In addition there is a change in the outer layers of the cell envelope as shown by the development of sensitivity to certain hydrolytic enzymes, in particular lysozyme (Hambleton, 1970). Permeability changes resulting from aerosolization may not be lethal in themselves but are related to subsequent survival of the airborne bacteria (Anderson et al. 1968; Hambleton, 1970).

The exact nature of the lesions resulting in permeability changes is unclear. In the case of sensitivity to lysozyme, however, a number of treatments induce susceptibility in Gramnegative bacteria previously resistant to the enzyme (Salton, 1957; Noller \& Hartsell, 196I ; Leive, I968; Heppel, I969). Susceptibility to the action of lysozyme may arise by conformational or chemical changes in the wall structure, possibly with concomitant release of a specific wall component such as lipopolysaccharide (Leive, 1968; Leive, Shovlin \& Mergenhagen, I968; Rogers, Gilleland \& Eagon, 1969) so that the mucopeptide wall layer becomes accessible to the enzyme. Aerosolization appears to result in a similar lesion of the envelopes of coliform bacteria.

The recovery of aerosolized Escherichia coli $\mathrm{B}$, shown by a return of resistance to lysozyme, was studied to determine the conditions that induced maximum repair. Also, materials released from $E$. coli в by aerosolization or ethylenediamine-tetraacetic acid (EDTA) were compared immunologically. The information obtained might indicate the nature of the wall lesion and the similarity, or otherwise, of the effects of aerosolization and other treatments upon the Gram-negative cell envelope. 


\section{METHODS}

Preparation of spray suspensions. A stock culture of Escherichia coli strain B was maintained as frozen pellets at $-70^{\circ}$ (Cox, I968). Cultures for experiments were prepared as described previously by Hambleton (1970). Organisms were harvested in a bench centrifuge ( $3000 \mathrm{~g}$, Io min.), washed twice with distilled water and finally resuspended in distilled water (about Io ${ }^{10}$ viable bacteria $/ \mathrm{ml}$.).

Generation and collection of aerosols. Aerosols were generated using a 3-jet Collison spray (Green \& Lane, 1957) and mixed with a secondary air supply of controlled relative humidity (RH) in a Henderson (I952) apparatus. Samples of aerosols aged for I sec. were collected by raised impingers (May \& Harper, 1957) containing Io ml. collecting fluid. The collecting fluids were $20 \mathrm{~mm}$-sodium phosphate buffer, $\mathrm{pH}_{7} \cdot 0$, I M-sucrose in $20 \mathrm{~mm}$-phosphate buffer and a chemically defined growth medium (GM 2) containing (w/v): glycerol (I \%); ammonium citrate (0.5 \%); $\mathrm{KH}_{2} \mathrm{PO}_{4} .3 \mathrm{H}_{2} \mathrm{O}(\mathrm{I} \%) ; \mathrm{MgSO}_{4} .7 \mathrm{H}_{2} \mathrm{O}(0.05 \%) ; \mathrm{NaCl}(0.05 \%)$; and ferric ammonium citrate $(0.0005 \%)$; the $\mathrm{pH}$ value was 7.0 .

The sensitivity of bacteria to lysozyme. Suspensions $\left(5 \times 10^{7}\right.$ organisms $/ \mathrm{ml}$.) of bacteria recovered from aerosols and diluted unsprayed suspensions were assayed for sensitivity to lysozyme ( $50 \mu \mathrm{g} . / \mathrm{ml}$.) by the procedure described by Hambleton (I970). Numbers of viable organisms were determined before and after incubation with lysozyme.

Wall repair by aerosolized bacteria was assessed by the recovery of resistance to lysozyme as follows. Suspensions of bacteria recovered from aerosols were incubated in the collecting fluid for $\mathrm{I} \mathrm{h}$. at $37^{\circ}$ and the sensitivity of the bacteria to lysozyme tested at intervals. In some experiments, the following compounds were added singly to the suspension of aerosolized organisms in medium GM 2 before incubation: chloramphenicol $(50 \mu \mathrm{g} . / \mathrm{ml}$.), actinomycin $\mathrm{D}$ (Io $\mu \mathrm{g}$. $/ \mathrm{ml}$ ), penicillin G (I000 units $/ \mathrm{ml}$ ), and 2,4-dinitrophenol (5 mM).

To prevent interference with subsequent viability assays these compounds were removed by centrifuging ( $5 \mathrm{~min}$. at $3000 \mathrm{~g}$ ) and washing the bacterial suspensions twice with the appropriate collecting fluid, before testing for sensitivity to lysozyme.

Estimation of bacterial numbers. Total numbers of bacteria were determined with a Thoma counting chamber. Viable bacteria were estimated by plating samples $(0.25 \mathrm{ml}$.) of the suspensions, diluted in the appropriate collecting fluid, on to tryptone agar plates; colonies were counted on four replicate plates after incubation for $20 \mathrm{~h}$. at $37^{\circ}$.

Effect of cations and inhibitors on lysozyme. Micrococcus lysodeikticus from the laboratory collection was grown overnight in nutrient broth (Oxoid no. 2 nutrient broth, $25 \mathrm{~g}$./1.; Oxoid L 2 I yeast extract, $4 \mathrm{~g}$./1., $\mathrm{pH} 7 \cdot 4$ ) at $37^{\circ}$ with shaking. Organisms were harvested by centrifuging ( $3000 \mathrm{~g}$, I0 min.), washed once in $20 \mathrm{~mm}$-phosphate buffer, $\mathrm{pH} 7{ }^{\circ}$, and resuspended in phosphate buffer $(E 540 \mathrm{~nm}$. I $\cdot 0)$. Lysozyme was added to the suspension and lysis of the bacteria at room temperature observed as a decrease in turbidity at $540 \mathrm{~nm}$. This procedure was repeated with suspensions of $M$. lysodeikticus to which were added singly $\mathrm{Mn}^{2+}, \mathrm{Ca}^{2+}, \mathrm{Fe}^{3+}, \mathrm{Zn}^{2+}, \mathrm{Mn}^{2+}$ (each $10 \mathrm{mM}$ ); chloramphenicol (50 $\mu \mathrm{g} . / \mathrm{ml}$ )); actinomycin D (Io $\mu \mathrm{g} . / \mathrm{ml}$.); penicillin G (1000 units $/ \mathrm{ml}$.); and 2,4-dinitrophenol (5 mM).

Preparation of material released by aerosolization or EDTA treatment. A suspension of Escherichia coli в ( $\mathrm{I}^{11}$ viable organisms $/ \mathrm{ml}$.) was aerosolized and a sample of the cloud collected into phosphate buffer $(20 \mathrm{ml}$.) after it had travelled along the exposure tube for I sec. This process was continued for $30 \mathrm{~min}$. and resulted in recovery of a thick suspension (about $10^{10}$ organisms $/ \mathrm{ml}$.). Bacteria were removed by centrifuging and the supernatant fluid was sterilized by filtration through a membrane filter (Oxoid, grade 0.45 , Oxoid Ltd, Southwark Bridge Road, London). The filtrate was freeze-dried and the residue taken up in 
2.0 $\mathrm{ml}$. of distilled water, dialysed for $8 \mathrm{~h}$. against distilled water (to remove salts), again freeze-dried and finally dispersed in $0.5 \mathrm{ml}$. of distilled water.

Escherichia coli в was treated with EDTA as described by Leive et al. (1968) and the released material isolated as described for aerosolized cells.

Immunological tests. Materials released from Escherichia coli в by aerosolization or EDTA treatment were tested for immunological activity by the agar-gel double diffusion technique (Ouchterlony, 1953). Both preparations were allowed to diffuse against rabbit anti-E. coli B serum.

Materials. Lysozyme and 2,4-dinitrophenol were obtained from B.D.H. Chemicals Ltd, Poole, Dorset. Chloramphenicol was from Parke Davis \& Co Ltd, Hounslow, Middlesex, and penicillin G (Crystapen) from Glaxo Laboratories Ltd, Greenford, Middlesex. Actinomycin D was a gift from Dr A. Andrew, Merck, Sharp \& Dohme Ltd, Hoddesdon, Hertfordshire.

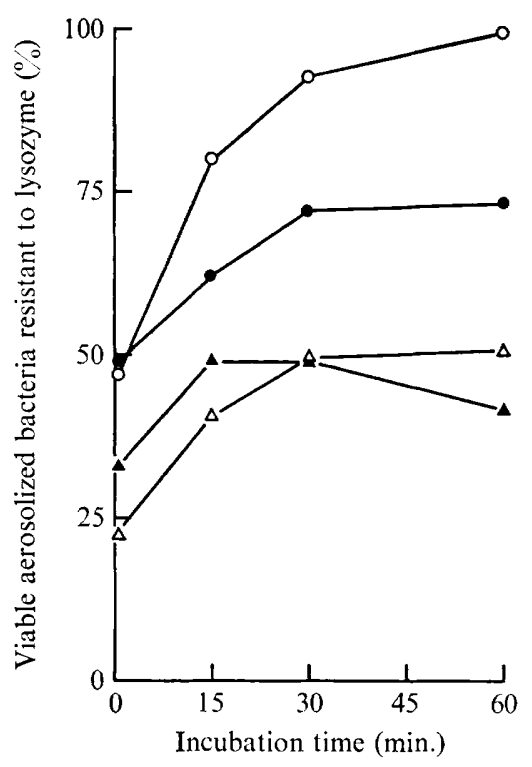

Fig. I. Wall repair by aerosolized Escherichia coli в organisms. Bacteria were sprayed from distilled water and held in an aerosol at $75 \% \mathrm{RH}$ for I sec. Samples were collected into and incubated for $\mathrm{I} h$. at $37^{\circ}$ in GM2 medium (O); GM 2 medium without glycerol and citrate $(\triangle)$; GM 2 medium without $\mathrm{Mg}^{2+}$ and $\mathrm{Fe}^{3+}(\boldsymbol{\odot})$; GM 2 medium containing 2,4-dinitrophenol $(5 \mathrm{mM}, \boldsymbol{\Delta})$ and their sensitivity to lysozyme assayed at intervals.

\section{RESULTS}

Before aerosolization, Escherichia coli B organisms were resistant to the bactericidal effect of lysozyme. Even after incubation of a diluted suspension of unsprayed bacteria $\left(5 \times 10^{7}\right.$ organisms $/ \mathrm{ml}$.) with the enzyme $\left(50 \mu \mathrm{g}\right.$. $/ \mathrm{ml}$.) for I h. at $37^{\circ}$ the maximum decrease in viability observed was always less than $2 \%$. In all the experiments described below the aerosols of $E$. coli в were aged for I sec. at $75 \% \mathrm{RH}$ before sampling. The viability of bacteria (in the absence of lysozyme) recovered from such aerosols generally exceeded $85 \%$ in all the collecting fluids used (Table I) but considerable proportions of the bacteria were sensitive to lysozyme (Fig. I).

Wall repair was estimated by the increase (within I h.) of the number of micro-organisms resistant to lysozyme treatment. The increase was not due to multiplication of lysozyme 
resistant organisms during the incubation period because cell division during the first hour of incubation was insignificant (Table $\mathrm{I}$ ). Some cell division did occur during the second hour of incubation in medium GM 2 whereas viability decreased when $\mathrm{Mg}^{2+}$ and $\mathrm{Fe}^{3+}$ were not present in the medium.

Table I. Viability of Escherichia coli в sprayed from distilled water, stored in an aerosol at $75 \% \mathrm{RH}$ for I sec. and sampled into various collecting fluids

Bacterial suspensions were incubated at $37^{\circ}$ for up to $2 \mathrm{~h}$.; viable and total bacterial counts were determined at intervals.

Collecting fluid

$20 \mathrm{~mm}$-Sodium phosphate buffer, $\mathrm{pH} 7 \cdot 0$

I M-Sucrose in $20 \mathrm{~mm}$ phosphate buffer

GM 2* without $\mathrm{Mg}^{2+}$ and $\mathrm{Fe}^{3+}$

GM 2*

$\begin{array}{rccc}\begin{array}{r}\text { Incubation } \\ \text { time (min.) }\end{array} & \begin{array}{c}\text { Total count } \\ \left(\mathrm{ml} .^{-1} \times \mathrm{IO}^{-7}\right)\end{array} & \begin{array}{c}\text { Viable count } \\ \left(\mathrm{ml} .^{-1} \times \mathrm{IO}^{-7}\right)\end{array} & \begin{array}{c}\text { Ratio } \\ \text { viable/total }\end{array} \\ 0 & 6.8 & 5.3 & 0.78 \\ 30 & 6.8 & 5.9 & 0.86 \\ 60 & 7.2 & 6.1 & 0.84 \\ 90 & 7.2 & 5.6 & 0.78 \\ 120 & 6.8 & 5.6 & 0.82 \\ 0 & 7.2 & 9.6 & 1.3 \\ 30 & 6.4 & 7.5 & 1 \cdot 2 \\ 60 & 7.2 & 6.5 & 0.9 \\ 90 & 7.4 & 7.9 & 1.1 \\ 120 & 6.8 & 6.8 & 1.0 \\ 0 & 7.2 & 6.5 & 0.9 \\ 30 & 5.6 & 4.2 & 0.75 \\ 60 & 7.2 & 3.7 & 0.52 \\ 90 & 6.4 & 2.5 & 0.39 \\ 120 & 5.2 & 2.7 & 0.52 \\ 0 & 7.2 & 6.6 & 0.87 \\ 30 & 6.8 & 6.6 & 0.97 \\ 60 & 7.6 & 7.1 & 0.93 \\ 90 & 8.4 & 8.4 & 1.0 \\ 120 & 10.6 & 10.1 & 0.95\end{array}$

* See the Methods section.

Table 2. Effect of certain cations on the sensitivity of aerosolized Escherichia coli в suspensions to lysozyme $(50 \mu \mathrm{g} . / \mathrm{ml}$.)

Bacteria were sprayed from water, stored in an aerosol at $75 \% \mathrm{RH}$ for I sec. and collected into $20 \mathrm{~mm}$-sodium phosphate buffer $\mathrm{pH} 7 \cdot 0$. Portions of the suspension were incubated for $\mathrm{I} h$. at $37^{\circ}$ with one of the cations ( $10 \mathrm{mM}$ ). Sensitivity of the bacterial suspensions to lysozyme was tested before and after incubation for $\mathrm{I} h$. In the absence of lysozyme viable counts remained constant during incubation.

$\begin{array}{lcc}\begin{array}{c}\text { Viable organisms resistant to lysozyme }(\%) \\ \text { Time of incubation }\end{array} \\ \begin{array}{c}\text { O min. } \\ \text { (Io mM) }\end{array} \\ \text { None } & \begin{array}{c}60 \mathrm{~min} . \\ \text { (no added cation) }\end{array} \\ \mathrm{Mg}^{2+} & 18 & \text { I6 cation) } \\ \mathrm{Ca}^{2+} & 2 \mathrm{I} & 51 \\ \mathrm{Fe}^{3+} & 24 & 20 \\ \mathrm{Zn}^{2+} & 26 & 49 \\ \mathrm{Mn}^{2+} & 2 \mathrm{I} & 63 \\ & 26 & 35\end{array}$

$D i$ - and trivalent cations and wall repair. The structure and organisation of the cell walls of some micro-organisms appears to be partially dependent upon the binding of divalent cations (Asbell \& Eagon, 1966; Leive, I968). Some effects of di- and trivalent cations on the sensi- 
tivity of aerosolized Escherichin coli B organisms are shown in Table 2. Immediately after sampling only about $20 \%$ of the viable bacteria were resistant to the action of lysozyme. After incubation for $\mathrm{I} \mathrm{h}$. at $37^{\circ}$ in the presence of $\mathrm{Mg}^{2+}, \mathrm{Fe}^{3+}$ or $\mathrm{Zn}^{2+}(10 \mathrm{mM}) 5 \mathrm{I} \%, 49 \%$ and $63 \%$ respectively of the population were resistant; $\mathrm{Mn}^{2+}$ (IO $\mathrm{mM}$ ) was rather less effective (35\% resistant after $\mathrm{I}$ h.) and $\mathrm{Ca}^{2+}$ (IO $\mathrm{mm}$ ) had no effect. None of these cations affected the rate of lysis of Micrococcus lysodeikticus by lysozyme $(50 \mu \mathrm{g} . / \mathrm{ml}$.), showing that they did not inhibit the enzyme. As wall repair is complete only in the presence of a carbon-energy source (Fig. I) these results imply that the cations might be protecting the damaged wall from lysozyme attack, rather than leading to repair.
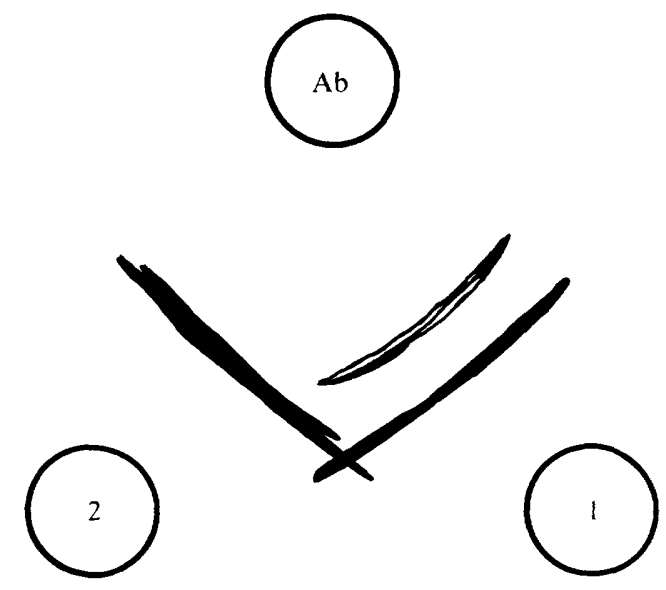

Fig. 2. Agar-gel diffusion pattern of material released from Escherichia coli B organisms by aerosolization ( 1 ) and by EDTA treatment (2) against rabbit anti-E. coli $\mathrm{B}$ serum (Ab).

Metabolism and wall repair. When aerosolized Escherichia coli в organisms were collected into and incubated in GM 2 medium, maximum wall repair occurred within $\mathrm{I}$ h. (Fig. I). Omission of the carbon-energy source from the medium profoundly decreased the extent of wall repair. The omission of $\mathrm{Fe}^{3+}$ and $\mathrm{Mg}^{2+}$ from the medium limited the repair process showing (Fig. I) that a cation requirement exists for the recovery of maximum resistance to lysozyme. Hence wall repair by aerosolized bacteria is a process requiring the presence of some multivalent cations coupled with active metabolism by the micro-organisms.

To define more clearly the metabolic processes contributing to repair, the effects of some substances of known inhibitory activity (P. Hambleton, unpublished results) were studied. Chloramphenicol $(50 \mu \mathrm{g} . / \mathrm{ml}$ ) $)$, an inhibitor of protein synthesis in bacteria, did not affect the rate of wall repair by aerosolized Escherichia coli $\mathrm{B}$. Inhibition of RNA synthesis by actinomycin D (Io $\mu \mathrm{g} . / \mathrm{ml}$ ), to which aerosolized $E$. coli B organisms are sensitive (P. Hambleton, unpublished results), only slightly impaired the rate of wall repair. Similarly the presence of penicillin $\mathrm{G}$ ( 1000 units $/ \mathrm{ml}$.) did not affect repair showing the process to be independent of cell wall mucopeptide synthesis. Medium GM 2 containing I M-sucrose was used to stabilize osmotically sensitive organisms during incubation with penicillin $G$. The sucrose was removed with the penicillin before testing for sensitivity of the bacteria to lysozyme.

One compound that did prevent wall repair was 2,4-dinitrophenol (5 mM). After incubation of aerosolized Escherichia coli B with this substance very little repair occurred during the time taken by control organisms fully to recover resistance to lysozyme (Fig. I). This indi- 
cates that metabolic pathways leading to energy production are essential to the repair process in aerosolized bacteria. All the potential inhibitors had no effect on the rate of lysis of Micrococcus lysodeikticus by lysozyme.

Immunological studies. The Ouchterlony agar-gel double diffusion technique was used to compare the immunological activity of material released from Escherichia coli в by aerosolization and by EDTA treatment. Both preparations were allowed to diffuse in agar gel against rabbit anti-E. coli $\mathrm{B}$ serum. The material released from aerosolized bacteria contained two components both of which differed immunologically from the one component released from EDTA treated organisms (Fig. 2).

\section{DISCUSSION}

The permeability of Escherichia coli B to certain enzymes (Hambleton, 1970) is markedly affected by aerosolization. Other effects on permeability control have been observed (Anderson et al. I968; J. E. Benbough, P. Hambleton \& R. E. Strange, unpublished results) which indicate that the effects of aerosolization on the cell envelope may be non-specific. The experiments described here shown that the repair of wall damage by aerosolized bacteria is similar to the restoration of permeability control which occurs in organisms recovering from EDTA treatment (Leive, I968).

A number of treatments that apparently alter the bacterial surface cause Gramnegative bacteria to become sensitive to lysozyme (Salton, 1957; Voss, 1967; Work, 1967; Wilkinson, 1968). Since cell-surface lipopolysaccharide (LPS) is external to the mucopeptide substrate of lysozyme a change in the structure of LPS could result in organisms becoming susceptible to this enzyme. Release of LPS from Gram-negative bacteria by treatments known to render the organisms sensitive to lysozyme has, in fact, been demonstrated (Leive et al. 1968; Rogers et al. 1969; Winshell \& Neu, 1970).

The relationship between permeability and the structure and organization of the envelope has been extensively studied with Gram-negative bacteria treated with EDTA (Repaske, 1958; Asbell \& Eagon, 1966; Leive, I968; Rogers et al. 1969; Winshell \& Neu, I970). Concomitant with changes in permeability, some wall LPS was released into the surrounding medium. Leive (1968) has demonstrated that the permeability changes induced in Escherichia coli в by EDTA can be reversed and that energy utilization is essential. The results described here show clearly that aerosolized $E$. coli B organisms can recover resistance to lysozyme under certain conditions.

Maximum wall repair only took place when bacteria were incubated in a complete nutrient medium. In the absence of multivalent cations recovery of resistance to lysozyme was incomplete. Minimum repair was achieved by organisms incubated in GM 2 medium lacking a carbon-energy source. The role of divalent cations in the maintenance of the structure and organization of the outer lipopolysaccharide-lipoprotein layers of the Gram-negative cell envelope has been discussed by Asbell \& Eagon (I966). Partial recovery of resistance to lysozyme by suspensions of aerosolized Escherichia coli B was mediated by $\mathrm{Mg}^{2+}, \mathrm{Zn}^{2+}$ and $\mathrm{Fe}^{3+}$ (10 $\mathrm{mM}$ ); these ions presumably exert their effect by stabilizing the stressed outer wall layers.

Wall repair is apparently independent of the functioning of a number of synthetic pathways in aerosolized bacteria. For example, when protein or RNA synthesis was inhibited by chloramphenicol or actinomycin D respectively, wall repair still occurred. Similarly, repair did not depend on synthesis of wall mucopeptide. Metabolism of a carbon-energy source is, however, essential for the restoration of resistance in aerosolized bacteria to lysozyme, as shown by the inability of the micro-organisms to repair in the presence of 2,4-dinitrophenol 
which uncouples oxidative phosphorylation (Gel'man, Lukoyanova \& Ostrovskii, 1967). These results show a basic similarity between the conditions necessary for wall repair by aerosolized bacteria and for the restoration of the permeability barrier by EDTA-treated bacteria (Leive, 1968), suggesting that the wall lesions resulting from both stresses are similar.

The immunological activity of the LPS released by EDTA-treatment of Escherichia coli has been examined by Leive et al. (I968). If the permeability changes in EDTA-treated micro-organisms results, at least in part, from a release of surface LPS (Leive, I968; Winshell $\& \mathrm{Neu}, \mathrm{1970}$ ) one might expect material of similar immunological specificity to be released from aerosolized bacteria. At least two antigens were released from aerosolized $E$. coli B organisms but the immunological reactivity of both differed from that of the single component released after EDTA treatment of the bacteria. Nevertheless, this is the first evidence that the development, by aerosolized bacteria, of susceptibility to lysozyme may be associated with the release of components from the cell envelope.

I wish to thank Dr D. C. Ellwood for stimulating discussion, Dr R. E. Strange and Dr J. E. Benbough for their help with the preparation of the manuscript and Mrs S. M. Marriott for technical assistance.

\section{REFERENCES}

Anderson, J. D., Dark, F. A. \& Peto, S. (1968). The effect of aerosolization upon survival and potassium retention by various bacteria. Journal of General Microbiology 52, 99-105.

Asbell, M. A. \& EAGON, R. G. (1966). The role of multivalent cations in the organisation and structure of bacterial cell walls. Biochemical and Biophysical Research Communications 22, 664-671.

Benbough, J. E. (1967). Death mechanisms in airborne Escherichia coli. Journal of General Microbiology 47, 325-333.

Cox, C. S. (1968). A method for the routine preservation of micro-organisms. Nature, London 220, I 39.

Cox, C. S. (1969). The cause of loss of viability of airborne Escherichia coli K I2. Journal of General Microbiology $57,77-80$.

Gel'man, N. S., Lukoyanova, M. A. \& Ostrovskit, D. N. (1967). Respiration and Phosphorylation of Bacteria. New York: Plenum Press.

Green, H. L. \& LANe, W. R. (1957). Particulate Clouds: Dusts, Smokes and Mists. London: E. and F. N. Spon.

HAMBLETON, P. (1970). The sensitivity of Gram-negative bacteria, recovered from aerosols, to lysozyme and other hydrolytic enzymes. Journal of General Microbiology 6r, 197-204.

Henderson, D. W. (1952). An apparatus for the study of airborne infection. Journal of Hygiene, Cambridge 5o, 53-68.

HeppeL, L. A. (1969). The effect of osmotic shock on release of bacterial proteins and on active transport. Journal of General Physiology 54, 95-I09.

LEIVE, L. (1968). Studies on the permeability change produced in coliform bacteria by ethylenediaminetetraacetate. Journal of Biological Chemistry 243, 2373-2380.

Leive, L., Shovlin, V. K. \& Mergenhagen, S. E. (1968). Physical, chemical and immunological properties of lipopolysaccharide released from Escherichia coli by ethylenediaminetetraacetate. Journal of Biological Chemistry 243, 6384-6391.

MAY, K. R. \& HARPER, G. J. (1957). The efficiency of various liquid impinger samplers in bacterial aerosols. British Journal of Industrial Medicine 14, 287-297.

Noller, E. C. \& HaRTsell, S. E. (I96I). Bacteriolysis of Enterobacteriaceae. I. Lysis by four lytic systems utilizing lysozyme. Journal of Bacteriology 81, 482-49I.

OUCHTERLONY, O. (1953). Antigen-antibody reactions in gels. IV. Types of reactions in coordinated systems of diffusion. Acta pathologica et microbiologica scandinavica 32, 23I-240.

REPASKE, R. (1958). Lysis of Gram-negative organisms and the role of versene. Biochimica et biophysica acta 30, 225-232. 
Rogers, S. W., Gilleland, H. E. Jun. \& Eagon, R. G. (1969). Characterization of a protein-lipopolysaccharide complex released from cell walls of Pseudomonas aeruginosa by ethylenediaminetetraacetic acid. Canadian Journal of Microbiology 15, 743-748.

Salton, M. R. J. (1957). The properties of lysozyme and its action on micro-organisms. Bacteriological Reviews 2I, 82-99.

Voss, J. G. (1967). Effects of organic cations on the Gram-negative cell wall and their bactericidal activity with EDTA and surface active agents. Journal of General Microbiology 48, 39I-400.

WeBb, S. J. (1969). The effect of oxygen on the possible repair of dehydration damage by Escherichia colt. Journal of General Microbiology 58, 317-326.

WiLkinson, S. G. (1968). Studies on the cell walls of Pseudomonas species resistant to EDTA. Journal of General Microbiology 54, I95-213.

Winshell, E. B. \& NeU, H. C. (1970). Relation of lipopolysaccharide and fatty acid ester release to the ethylenediaminetetraacetic acid alteration of permeability in Enterobacteriaceae. Journal of Bacteriology I02, 537-539.

WORK, E. (1967). Factors affecting the susceptibility of bacterial cell-walls to the action of lysozyme. Proceedings of the Royal Society B 167, 446-447. 